\title{
Impacts of fisheries on seabird communities*
}

\author{
ROBERT W. FURNESS \\ Institute of Biomedical and Life Sciences, Graham Kerr Building, University of Glasgow, Glasgow G12 8QQ, UK. \\ E-mail: r.furness@bio.gla.ac.uk
}

\begin{abstract}
SUMMARY: Long-line by-catch of albatrosses and petrels may soon lead to species extinctions. Set-net bycatch has caused major reductions in certain seabird populations. Some fisheries may decrease numbers of seabirds by reducing abundance of prey-fish. Other fisheries may increase seabird numbers, by increasing prey-fish abundance through depletion of predatory fish stocks, or by provision of offal and discards. These latter impacts of fisheries on seabirds are often difficult to measure against a background of many and varied environmental and human influences. Depletion of stocks of small lipid-rich fish have reduced numbers of seabirds, in Peru, the Norwegian Sea, and the Barents Sea. However, reductions of predatory fish stocks in the North Sea have more than compensated for quantities of sandeels removed by the sandeel fishery. While piscivorous fish stocks remain low, sandeel fishery and seabirds appear to be able to coexist. However, if piscivorous fish stocks recover in the North Sea, reduced availability of sandeels to seabirds may affect certain species. Provision of discards and offal can stimulate large increases in scavenging seabird numbers. Desirable reductions in discard rates may have an unfortunate side-effect of forcing some scavenging seabirds to turn to killing smaller seabirds, with drastic consequences for community structure.
\end{abstract}

Key words: conservation, discards, ecosystem, fisheries management, industrial fisheries, predator-prey, sandeel.

RESUMEN: El IMPACTO DE LAS PESQUERIAS EN LAS COMUNIDADES DE AVES MARINAS. - Las capturas accidentales de los albatros y petreles en palangres pueden llevar pronto a algunas especies a la extinción. La captura en redes de trasmallo ha causado también grandes reducciones en ciertas poblaciones de aves marinas. Ciertas pesquerías pueden provocar la disminución en el número de aves marinas al reducir la abundancia de los peces presa. Otras pesquerías pueden hacer crecer el número de aves marinas, al incrementar la abundancia de los peces presa mediante la disminución de las efectivos de los peces depredadores, o mediante el suministro de despojos y descartes. Estos últimos impactos de las pesquerías en las aves marinas son con frecuencia difíciles de medir por el efecto de numerosas y variadas influencias ambientales y humanas. La disminución de efectivos de pescado azul de pequeño tamaño ha reducido el número de aves marinas en Perú, el Mar de Noruega y el Mar de Barents. Sin embargo, en el Mar del Norte, la reducción del lanzón (A. marinus) como consecuencia de su pesca específica se ha visto ampliamente compensada por una reducción en los efectivos de peces predadores. Mientras los efectivos de peces piscívoros se mantengan bajos, la pesca del lanzón y las aves marinas parecen ser capaces de coexistir. No obstante, si los efectivos de peces piscívoros se recuperan en el Mar del Norte, reduciendo la disponibilidad de lanzones para las aves marinas, esto afectaría a ciertas especies. El aprovisionamiento de descartes y despojos pudiera estimular grandes incrementos en aves marinas carroñeras. La deseable reducción en las tasas de descartes pudiera tener un desafortunado doble efecto de forzar a las aves marinas carroñeras a que vuelvan a matar aves marinas de pequeño tamaño, con consecuencias drásticas para la estructura de la comunidad.

Palabras clave: Ammodytes marinus, conservación, descartes, ecosistema, gestión de pesquerías, lanzón, pesquerías industriales, predador-presa. 


\section{INTRODUCTION}

Fisheries may have adverse effects on seabirds in several quite different ways. Fisheries may cause incidental mortality of adult seabirds by drowning birds that become caught in fishing gear (Tasker et $a l ., 2000)$. It has long been known that small numbers of seabirds, especially of inexperienced young birds, can be drowned in lobster pots, in set nets, trawls or seines. However there have been two developments that have greatly increased bycatch of seabirds. Development of monofilament nylon nets resulted in very large numbers of birds being drowned because these nets are almost invisible to birds swimming underwater. Development of longline fisheries has resulted in large numbers of certain seabirds drowning as a result of their being attracted to long-lines in order to steal baits from hooks as these are deployed; occasionally birds make an error and swallow the hook as well as the bait. In some parts of the world, seabirds are harvested by fishermen to use as bait, or as food for fishermen; this habit has tended to become less common as fisheries have become more sophisticated.

As well as causing direct mortality, fisheries can affect seabirds by changing the availability of food. Industrial fisheries, exploiting fish that are important natural foods of seabirds (mostly small pelagic schooling fish) may deplete stocks and so reduce food availability to some seabirds (Cairns, 1987; Hamer et al., 1991; Furness and Camphuysen, 1997; Hunt et al., 1999). Examples of impacts of industrial fishing on seabirds have been seen in Peru, Norway and the Barents Sea (Duffy, 1983; Dunn, 1994, 1995; Barrett and Krasnov, 1996). A second kind of impact arises where fisheries make available to scavenging seabirds food that they could not naturally obtain for themselves. For example, fisheries catching benthic fish that are too deep for most seabirds to reach, and too large for those able to dive to the seabed to swallow, make these fish available to scavenging seabirds in the form of discards and offal (Hudson, 1989; Hudson and Furness, 1988, 1989; Camphuysen et al., 1995; Garthe et al., 1996; Moore and Jennings, 2000; Ojowski et al., 2001). The quantities of fish discarded by fisheries are enormous. About 25-30 million tons of fish was estimated to have been discarded worldwide each year during the 1990s (Alverson et al., 1994; Moore and Jennings, 2000). Impacts of discarding can be quite unexpected. For example, seabirds feeding on discards accumulate much higher levels of certain con- taminants, such as mercury, than when they are feeding on pelagic fish (Arcos et al., 2002).

Global impacts of fishing were reviewed recently by Tasker et al. (2000), based on case studies from all around the world, and with particular focus on fisheries causing direct mortality of seabirds. In this paper I shall highlight fisheries management issues that will affect the future conservation status of vulnerable seabird populations, with particular emphasis on the situation in Europe, where changes in seabird food supply caused by fisheries may result in alterations to seabird community structure, and affect predator-prey relationships within seabird communities.

\section{SOME THEORETICAL CONSIDERATIONS}

Most seabirds share a set of demographic values characteristic of strongly ' $\mathrm{K}$ '-selected animals: they have high adult survival rates (often $>90 \%$ p.a.), deferred maturity (in many species not starting to breed until 5-10 years old), and low fecundity (typically less than 0.5 chicks reared per pair per year). As a result, seabird populations can only increase slowly even under highly favourable environmental conditions, and any factor increasing adult mortality rate will have a particularly strong negative influence on population dynamics. In contrast, changes to reproductive output may have a much smaller impact, and one that only becomes evident after a considerable time lag. Although seabird monitoring programmes tend to focus for practical reasons on breeding numbers and breeding success, impacts on adult survival rates are of particular significance for seabird conservation.

\section{LONG-LINE BYCATCH}

A comprehensive and detailed review of the seabird long-line bycatch problem, and potential for mitigation measures, has been produced by Brothers et al. (1999), so this topic will be described only briefly here. There is general agreement among seabird conservationists that this is the most serious global seabird-fishery issue at present. Both pelagic long-line fisheries (mainly for tunas, swordfish Xiphias gladius and billfishes in temperate to tropical waters) and demersal long-line fisheries (for cod Gadus morhua, hake Merluccius merluccius, haddock Melanogrammus aeglefinus, torsk Brosme 
brosme, ling Molva molva and wolf-fish Anarhichas lupus in the North Atlantic, for Pacific cod Gadus macrocephalus, Pacific halibut Hippoglossus stenolepis, sablefish Anoplopoma fimbria or walleye pollock Theragra chalcogramma in the North Pacific, for hakes Merluccius sp., kingklips Genypterus sp., and Patagonian toothfish Dissostichus eleginoides in South America and South Africa, for kingklip, snapper Pagrus auratus and trevalla Hyperoglyphe antarctica in Australia and for Patagonian toothfish in the Southern Ocean) take a bycatch of seabirds that accidentally swallow hooks when stealing baits as long-lines are deployed behind fishing vessels (Brothers et al., 1999). Estimates of numbers of seabirds drowned by long-line fisheries are based on observations of small numbers of vessel-trips scaled up to the total number of hooks deployed by the fishery. These estimates involve multiplying a small number of birds recorded drowned by a very large number of hooks set; bird bycatch rates are generally less than 1 per 1,000 hooks set. They are complicated by the fact that many factors influence seabird bycatch rate but these factors are not well known (Brothers et al., 1999; Weimerskirch et al., 2000), and the data are not amenable to simple statistical analysis. The effectiveness of mitigation measures is also difficult to quantify given the multiplicity of factors affecting capture rate and the low capture rate per fishing vessel. Nevertheless, estimated bycatches of seabirds are large. For example, the northeastern Pacific longline fishery was estimated to drown over 13,000 seabirds per year from 1993-1996 (Brothers et al., 1999), most of which were northern fulmars Fulmarus glacialis. The South American Patagonian toothfish fishery was estimated to have drowned 2300 white-chinned petrels Procellaria aequinoctialis and 1,150 albatrosses in 1990/91 (Brothers et al., 1999), while the Southern Ocean Patagonian toothfish fishery may have drowned over a quarter of a million seabirds between 1996 and 1999 (Tasker et al., 2000). The Southern Ocean Japanese pelagic longline fishery was estimated to have drowned about 40,000 albatrosses per year during the 1980s (Brothers et al., 1999). Many of the birds drowned are from species with very large populations, such as the black-browed albatross Diomedea melanophris (ca 500,000 breeding pairs) or whitechinned petrel (several million breeding pairs). Population sizes and trends for albatrosses are generally well documented and vary from a few tens of breeding pairs in some species to hundreds of thousands of pairs in others; for a few populations detailed demographic data exist showing which particular component of the population is subject to elevated mortality rates due to long-line fishery bycatch. Several albatross and petrel species are already listed as 'Critically Endangered', 'Endangered' or 'Vulnerable' by the World Conservation Union, and long-line fisheries are contributing to population declines in several of these species, with a clear risk of species extinctions if current trends are allowed to persist, since drowning of only one or two adults per year from a breeding population of only a few tens of breeding pairs will cause population decline (Croxall and Gales, 1997; Belda and Sánchez, 2001). Mitigation measures are legally required in a number of regions and fisheries, but not all fisheries adopt these, and the efficacy of the many possible mitigation measures requires further study (Brothers et al., 1999; Weimerskirch et al., 1999), although there is no doubt that they can greatly reduce bycatch rates (Murray et al., 1993; Melvin and Parrish, 2001).

\section{SET-NET BYCATCH}

Monofilament gillnets represent a serious hazard for pursuit-diving seabirds (King, 1984; Tasker et $a l ., 2000)$. There are several examples where regional populations of seabirds have declined as a result of high mortality rates in monofilament nets, as in the eastern Canadian salmon fishery where an annual mortality of 20,000-30,000 common guillemots Uria aalge in Witless Bay, Newfoundland in the early 1970 s removed $13-20 \%$ of the local breeding population per year (Piatt et al., 1984), or in northern Norway where during the mid-1960s to mid1980s gillnets for cod and salmon drowned many tens of thousands of common and Brünnich's guillemots Uria lomvia, and breeding numbers at local colonies declined dramatically, for example from 220,000 to 10,000 guillemots at Hjelms $\varnothing y$ between 1965 and 1985 (Vader et al., 1990).

The largest mortality of seabirds associated with gill nets was in the North Pacific high seas salmon and squid drift-net fisheries which were thought to have killed about 500,000 seabirds per year before the closure of these fisheries in 1992 (DeGange et al., 1993). These large figures involved mostly shearwaters from populations that breed in enormous numbers in the southern hemisphere, and probably had very little impact on those very abun- 
dant birds. More obvious impacts arise where gillnets are used in summer close to major breeding colonies, in which case local breeding numbers can be noticeably reduced (Tasker et al., 2000).

Seabirds can also become entangled in lost or discarded fragments of fishing gear. In particular, northern gannets Morus bassanus and various cormorant species will collect such materials to use in nest construction, which can lead to entanglement of adults and especially of chicks. Mortality rates resulting from this are low, but this form of pollution has increased considerably over recent decades (Montevecchi, 1991).

\section{REDUCTION IN STOCKS OF SMALL LIPID-RICH SHOALING FISH}

Although many oceanic or pelagic seabirds feed extensively on cephalopods or crustacea, most continental shelf and shallow sea seabirds feed predominantly on abundant, small, shoaling pelagic fish, at least during the breeding season (Furness, 1990; Bailey et al., 1991; Montevecchi, 1993; Springer and Speckman, 1997). Small shoaling fish species are often targets of industrial fisheries for production of fish meal and oils. The removal of large quantities of these fish by industrial fisheries might reduce food supply to seabirds. One frequently quoted example of this has been in Peru, where environmentally-driven dramatic decreases in numbers of guano seabirds occurred regularly during El Niño events. Seabirds recovered between these events to show cyclic fluctuations, but as the Peruvian anchovy Engraulis ringens fishery increased, seabird numbers began to fail to recover after El Niño driven crashes, to such an extent the seabird population fell to only a small fraction of its earlier numbers (Duffy, 1983).

Considered in abstract terms, industrial fishing could hypothetically affect seabird populations through a number of distinct processes. Fishing might reduce stock biomass, so the prey density available to foraging seabirds, during the seasonal period of the fishery or subsequently, might fall below levels that would support high breeding success or survival. Such an effect would depend on whether seabirds require a certain minimum prey density to be available before foraging becomes economic. Over a longer term, fishing might reduce the mean level, or increase the variability, of recruitment into the fished stock. Such an effect would come about if fishing reduced spawning stock biomass and this reduction affected the level of recruitment of young fish. Thus, the form of any relationship between spawning stock biomass and recruitment is of fundamental interest with regard to possible effects of such fisheries on seabird food supply. Finally, industrial fishing might alter the food-web structure by affecting the competitive balance between fished and unfished, or between heavily fished and lightly fished stocks. For example, the relative abundance of two ecologically similar small planktivorous fish species might change in such a way that species A decreased and species B increased over a period of heavy fishing on species A. If species A was the staple prey of seabirds while species B was unavailable to them or uneconomic, this change in community composition could have an adverse effect on seabirds, whereas if species B was the staple prey of seabirds, then a high fishing effort on species A might increase food availability to the seabirds and could result in an increase in seabird numbers as a result.

Seabirds are generally long-lived, mostly producing few fledglings that will only recruit if they survive to several years old. In stark contrast, small pelagic fish exhibit short life spans, with early and highly variable recruitment. Their populations therefore tend to fluctuate rapidly, and rather unpredictably, in abundance. Seabird population sizes cannot track short-term changes in prey population abundance. Thus, seabirds have a variety of buffering mechanisms to cope with such natural variations in food supply. These vary among species in strength and form (Phillips et al., 1996). Theory predicts that the most vulnerable seabird species to reductions in pelagic food supplies would be small surface-feeding seabird species with specialised and energetically expensive foraging methods and little spare time to allow any increase in foraging effort, and this prediction is supported by empirical data (Furness and Tasker, 2000). Arctic terns Sterna paradisaea and black-legged kittiwakes Rissa tridacty$l a$ in Shetland were particularly severely affected by the apparently oceanographically-driven (Wright, 1996) reduction in sandeel stocks there in the late 1980s, whereas some of the larger seabirds continued to breed successfully despite the decline in sandeel abundance (Heubeck, 1989; Furness and Tasker, 2000). Theory also predicts that seabird species would maintain high adult survival rates even in the face of moderately reduced fish abundances, but that breeding success and time budgets 
would show responses to food supply (Cairns, 1987). Some data support this (Hamer et al., 1991, 1993; Phillips et al., 1996; Furness and Camphuysen, 1997; Harris and Wanless, 1997) but in several cases even adult survival may be affected by reductions in pelagic fish stocks (Vader et al., 1990; Hamer et al., 1991; Harris and Bailey, 1992; Krasnov and Barrett, 1995; Barrett and Krasnov, 1996; Oro and Furness, 2002).

Major industrial fisheries in Europe include the fisheries for capelin Mallotus villosus in the Barents Sea (Gjøsæter, 1995, 1997) and for sandeels in the North Sea (Gislason and Kirkegaard, 1996). These two fish species are extremely abundant lipid-rich fish that are a major part of the diet of many seabirds, so seabirds might be in direct competition with industrial fisheries for these resources (Furness and Tasker, 2000). The fact that these fisheries are well documented and that there are very detailed data on the numbers and breeding success of seabirds in these regions means that these cases provide the best opportunity to detect effects of industrial fishing on seabird populations.

The Barents Sea capelin stock has a historical biomass of 6-10 million tonnes, and serves as a food supply for cod, whales, seals and seabirds (Gjøsæter, 1997). It supported an industrial fishery taking 1-3 million tonnes of capelin between 1973 and 1984, but the capelin stock collapsed to 20,000 $\mathrm{t}$ in 1987, recovered rather rapidly until 1992 but then collapsed again in 1993-95 (op. cit.). Although the industrial fishery contributed to the first collapse by removing fish from a rapidly declining stock, the main cause of the collapse was high predation levels from increased stocks of cod (Bogstad and Mehl, 1997). Quantities of capelin taken by seabirds (Mehlum and Gabrielsen, 1995) were very small by comparison to quantities taken by cod, marine mammals or the industrial fishery (Gjøsæter, 1997), but the reduction in capelin abundance resulted in an $80 \%$ decrease in numbers of common guillemots in 1985-87, apparently as a result of starvation leading to mortality of young and adult birds in winter (Vader et al., 1990; Krasnov and Barrett, 1995; Anker-Nilssen et al., 1997). However, some seabirds showed surprisingly little response to this huge decrease in capelin stock. For example, seabirds on Hørnøya, north Norway, continued to achieve high breeding success and fed predominantly on capelin during the period of minimum stock (Barrett and Furness, 1990), possibly exploiting a local fjordic stock of capelin rather than the Barents Sea stock.
In the North Sea, many fish stocks are very heavily exploited. An industrial fishery developed during the 1950s, first harvesting young herring Clupea harengus, then taking mackerel Scomber scombrus, and after these stocks collapsed fishing mainly for Norway pout Trisopterus esmarkii and sandeels (mainly Ammodytes marinus).

The sandeel has become the main target of industrial fishing in the North Sea. Sandeel catch by the North Sea industrial fisheries increased from a low level in the late 1950s up to a peak of 1,039,000 $\mathrm{t}$ in 1989. By comparison, seabirds consume only about $200,000 \mathrm{t}$ of sandeels per year, but predominantly from the northwest sector of the North Sea, which is an area where industrial fishing for sandeels has contributed only a very small fraction of the total North Sea harvest (Furness and Tasker, 1997). The extent to which seabirds might be affected by the fishery depends particularly on the stock-recruitment relationship. For the North Sea as a whole, abundance of 0-group sandeels on 1 June each year shows a negative correlation with total sandeel stock biomass in January $\left(\mathrm{r}_{11}=-0.61, \mathrm{p}<0.05\right)$ and also a negative correlation with sandeel abundance estimated from catch-per-unit-effort data (Furness, 1999a, 2002). This suggests that there is a negative feedback operating, possibly through competition between young and older sandeels for shared food resources, that will tend to compensate for reduction in stock size by enhanced recruitment of young fish.

The black-legged kittiwake is one of the most abundant and widespread breeding seabirds in Europe, and it feeds very extensively on sandeels during the breeding season (Furness, 1990; Harris and Wanless, 1997). Many features of its biology suggest that it should be particularly vulnerable to reductions in food supply, such as its surface feeding habits, the fact that one adult is always present to protect the nest site, its relatively small size, high foraging costs (prolonged flapping flight) and specialised diet (Furness and Tasker, 2000). Additionally, empirical data confirm that black-legged kittiwake breeding success is strongly affected by food abundance (Harris and Wanless, 1990, 1997; Hamer et al., 1993; Rindorf et al., 2000). Thus, the kittiwake is the most obvious seabird to study in relation to effects of industrial fishing for sandeels on seabirds in the North Sea.

From the mid-1970s the industrial fishery has consistently caught more than 500,000 t but has increased very little, whereas before the mid-1970s the sandeel catch was below that level. The mean annual sandeel 
catch during 1986-95 was significantly higher than during 1975-85 $\left(\mathrm{t}_{19}=3.51, \mathrm{P}<0.05\right)$. Thus, any effects on black-legged kittiwake breeding numbers or breeding success might be expected to become most evident after 1986, on the east coast of England and southern Scotland where fishery catches have been larger than further north.

Black-legged kittiwake breeding numbers have increased since the turn of the century in all areas of the British Isles. Between national censuses in 1969 and 1987, the increase in kittiwake breeding numbers was high on the east coasts of England (+167\%) and Scotland $(+44 \%)$, but low in Shetland, Orkney and much of western Britain and Ireland (Lloyd et al., 1991). Between 1986 and 1995, the rate of annual change in breeding kittiwake numbers at selected monitoring colonies (Thompson et al., 1997) showed no significant difference between regions on the North Sea coast, which are potentially affected by the North Sea sandeel fishery (mean rate of increase $2.12 \%$ p.a., s.d. 2.57) and regions to the west of the British Isles, where sandeel fishing is negligible or non-existent (mean rate of increase $1.2 \%$ p.a., s.d. 1.74), but kittiwake numbers have been decreasing at Shetland (-6.9\% p.a.), which is a faster decline than seen in any other region, consistent with the collapse of the Shetland sandeel stock during the late 1980s.

Kittiwake productivity monitoring data for the years 1986-96 show that the mean breeding productivity in Shetland (mean 0.53 chicks per nest, s.d. 0.28 ) was significantly lower than in other regions (mean 0.84 chicks per nest, s.d. 0.29) of the British Isles $\left(\mathrm{t}_{64}=3.27, \mathrm{P}<0.05\right)$. However, excluding Shetland, breeding success was significantly higher at colonies adjacent to the North Sea sandeel fishery (mean 0.97 chicks per nest, s.d. 0.28) than at colonies in western parts of the British Isles (mean 0.65 chicks per nest, s.d. 0.20$)\left(t_{53}=4.57, \mathrm{P}<0.05\right)$.

Breeding productivity of kittiwakes monitored in Shetland, and in areas of the North Sea coast, showed significant correlations with the abundance of sandeels (Furness, 1999a). Kittiwake productivity at North Sea colonies also correlated with sandeel CPUE throughout the North Sea fishery (Furness, 1999a), indicating that good years for the fishery also tended to be good years for kittiwake breeding.

The ICES Multispecies Assessment Working Group (ICES, 1997) estimated that over the last three decades, mackerel, whiting, haddock, gurnards and the industrial fishery were the largest consumers of sandeels in the North Sea, but the amounts taken by these consumers varied considerably over years, primarily as a result of changes in predator population sizes. In particular, the North Sea stock of mackerel collapsed in the early 1970s and has failed to recover since, so that the mass of sandeels consumed by North Sea mackerel has fallen dramatically, from almost two million tonnes in 1974 to less than 100,000 t each year from 1986-93. In addition, the Atlantic stock 'western mackerel' migrates into the northern North Sea to a variable extent from year to year and consumes North Sea sandeels. Consumption by this stock is variable across years as a result. Consumption of sandeels by other predators is estimated to be much less than by mackerel. However, there has been a downward trend in consumption by whiting and by haddock as these stocks have decreased from the 1970s to the 1990s. During this period, however, the industrial catch of sandeels has grown. Adding together the industrial catch with the consumption by mackerel (North Sea and western stocks when in the North Sea), whiting, haddock and seabirds, the summed consumption of sandeels shows virtually no overall change from 1976 to 1995 (Furness, 2002).

\section{DISCHARGE OF OFFAL AND DISCARDS}

Although it is clear from recent research that discards and offal can be a very important food for certain seabirds in many different parts of the world (Abrams, 1983; Dändliker and Mülhauser, 1988; Hudson and Furness, 1988, 1989; Ryan and Moloney, 1988; Blaber and Wassenberg, 1989; Berghahn and Rosner, 1992; Furness et al., 1992; Thompson, 1992; Camphuysen, 1994; Evans et al., 1994; Garthe and Hüppop, 1994; Walter and Becker, 1994, 1997; Blaber et al., 1995; Camphuysen et al., 1995; Thompson and Riddy, 1995; Arcos and Oro, 1996; Garthe et al., 1996, 1999; Chapdelaine and Rail, 1997; Freeman, 1997; Walter, 1997; Oro and Ruiz, 1997; Walter and Becker, 1998; Freeman and Smith, 1998; Votier et al., 2001), the extent to which this supplementary food supply affects breeding success and population trends of scavenging seabirds is less clear (Howes and Montevecchi, 1992; Noordhuis and Spaans, 1992; Oro, 1996; Oro et al., 1995, 1996a, b; Furness, 1999b; Tasker et al., 1999). There is evidence to indicate large increases of scavenging seabird populations where large quantities of discards have been generated (Furness, 
1999b; Chapdelaine and Rail, 1997; Garthe et al., 1999), and evidence suggesting that reductions in discard rates adversely affect scavenging seabird breeding and population size (Hamer et al., 1991; Paterson et al., 1992; Oro, 1996; Oro et al., 1995, 1996a, b, 1997; Oro and Pradel, 1999, 2000). Recent research showed that reduced availability of discards in winter results in a decrease in body condition of large gulls (Hüppop and Wurm, 2000).

Seabird utilisation of discards has been studied in most detail in the North Sea and in the western Mediterranean. Fisheries in the North Sea generate very large quantities of discards. Estimates vary, partly as a result of low sampling intensity (Stratoudakis et al., 1998); the Scottish gadoid fishery is especially well studied but only $0.1-0.2 \%$ of trips is sampled (Stratoudakis et al., 1999), but recent annual discards have been estimated to amount to around $60,000 \mathrm{t}$ of offal and $500,000 \mathrm{t}$ of fish per year (Alverson et al., 1994; Evans et al., 1994; Garthe et al., 1996, 1999; Walter, 1997; ICES, 1998; Stratoudakis et al., 1998, 1999; Tasker et al., 1999; Reeves and Furness, 2002). Fisheries for demersal fish in the western Mediterranean also generate large quantities of discards, although there are fewer data on discard volumes here than for the North Sea (Oro and Ruiz, 1997). In recent years reductions in discarding by these fisheries (Reeves and Furness, 2002) appear to be having serious impacts on entire seabird communities rather than just on the scavenging species themselves. Large scavenging seabirds unable to find sufficient discards have been turning to predation on smaller seabirds to supply their food needs (Regehr and Montevecchi,1996; Russell and Montevecchi, 1996; Furness, 1999b; Phillips et al., 1999). A 50\% drop in numbers of kittiwakes in Shetland in the last 10 years can be attributed partly to increased killing by great skuas (Heubeck et al., 1997, 1999; Oro and Furness, 2002), which had previously been able to feed on sandeels and discards without needing to kill many other seabirds. These trends also suggest further ecological problems for the future, since it is general policy to reduce the quantities of discards and offal discharged at sea (FAO, 1995) and current changes in technical measures in the northern North Sea demersal fisheries are anticipated to cause a further reduction in quantities discarded over the next few years (Reeves and Furness, 2002). Similarly, yellow-legged gulls Larus cachinnans in Mediterranean colonies cause breeding failures and increased mortality of other seabirds due to increased predation and kleptoparasitism during periods when the local trawl fishery is closed so no longer generating discards (Oro and Martínez-Vilalta, 1994; Oro et al., 1997, 1999).

\section{DISCUSSION}

\section{North Sea sandeel fishing and seabirds}

The decline in breeding numbers of kittiwakes at Shetland since 1986 contrasts with the general increasing trend in most other areas of the British Isles. This decline has been attributed to predation of both kittiwake chicks and adults by great skuas Catharacta skua (Heubeck et al., 1997) as a result of reduced sandeel abundance combined with declining quantities of discards in the late 1980s. Thus, low stocks of sandeels can impact kittiwakes directly by reducing breeding success through food shortage (Hamer et al., 1993; Harris and Wanless, 1997), but also through the indirect effect of increased predator impact (Oro and Furness, 2002; see also Regehr and Montevecchi, 1996). The decrease in sandeel abundance at Shetland had little or no effect on the breeding success of common guillemots, but did affect their population during winter (Heubeck et al., 1991), so the timings and mechanisms of effects of low food abundance can vary from species to species.

In contrast to the clear effect of reduced sandeel abundance on kittiwakes in Shetland, kittiwakes breeding on the east of Britain, which might be expected to display responses to changes in sandeel stocks through the rest of the North Sea, showed no difference in mean population growth rate from kittiwakes monitored at colonies on the west of Britain and in Ireland. Furthermore, sustained high catches of sandeels since 1986 occurred as kittiwake numbers at the monitoring colonies continued to increase on the North Sea coast. Breeding success of kittiwakes on the North Sea coast was significantly higher than on the west of Britain and Ireland, suggesting that food supply to kittiwakes in the North Sea was at least as good as elsewhere despite the industrial fishery (Furness, 2002). One possible reason for this result may be the fact that the quantity of sandeels removed by the industrial fishery is less than the quantity that used to be removed by major fish predators. Since the stocks of these major fish predators have fallen, the total consumption of sandeels has remained almost constant since 1976. 
Given that the mackerel stocks were much higher during the late 1960s and early 1970s, it seems that sandeel consumption by fish predators would have been much higher before 1976, so the industrial fishery appears to have filled a niche vacated by North Sea mackerel when their stock collapsed. These data suggest that the mackerel is a keystone predator in the North Sea pelagic food web, and that reduction in the mackerel stock has improved the food supply to seabirds. Whether recovery of mackerel stocks in the North Sea would be compatible with a sustained industrial fishery and continued historically high populations of seabirds is unknown, but seems unlikely (Furness, 2002).

Environmental changes can affect seabird populations through 'bottom-up' effects on foodwebs (Ainley et al., 1995). Aebischer et al. (1990) showed that kittiwakes, as well as marine organisms at other trophic levels, responded to long term variations in environmental conditions in the North Sea. Changes in sandeel abundance in Shetland during the late 1980s are thought to have been driven by changes in oceanographic patterns affecting recruitment of sandeels at Shetland, and not by the industrial fishery for Shetland sandeels (Wright, 1996). There is evidence that seabird distribution at sea can be a response to sandeel distribution (Wright and Begg, 1997), but over recent decades, the industrial fishery for sandeels in the North Sea has tended to harvest predominantly from areas of the North Sea where seabird foraging densities are low (Wright et al., 1997). This comes about because most feeding on sandeels by seabirds occurs during the breeding season, when seabirds are constrained to forage in the vicinity of their colonies, and the majority of seabirds breeding in the North Sea are found in the northwestern sector, where industrial fishing for sandeels has traditionally been very slight.

The fact that breeding performance of kittiwakes in Orkney, in east Scotland and in east England each show significant correlation with VPA estimated numbers of 1-group sandeels in the North Sea is noteworthy. Firstly, the kittiwakes in Orkney will not be foraging in the southern North Sea while breeding; they will only be sampling sandeels from relatively close to Orkney (data from Shetland and the Isle of May suggest that kittiwakes generally forage within $50 \mathrm{~km}$ at most from colonies while rearing chicks). Although traditionally the North Sea sandeel stock is treated as a single stock, it is likely that there are separate stocks in different parts of the North Sea. The broad correlations between kitti- wake performance and aggregated sandeel data for all the North Sea suggest that sandeel stock dynamics are fairly coherent across years from Orkney to east England at least.

It appears that the sandeel fishery in the North Sea has had very little, if any, influence on the numbers of seabirds breeding on North Sea coasts until recently. Whether it is now affecting breeding numbers is uncertain; there is evidence suggesting that it had slight effects on breeding success of some species at colonies on the southeast coast of Scotland in the early 1990s (Rindorf et al., 2000). Continued monitoring of breeding performance, together with complete censuses of seabird breeding populations on the coasts of Britain in 2000 may shed further light on this. The broad picture developing from the analyses presented here suggests that interspecies interactions involving stocks of mackerel and piscivorous gadoids will be the most influential factor affecting future availability of sandeels to seabirds (Furness, 2002). Given the very high consumption of sandeels by the large stocks of mackerel and gadoids present before the 1970s, it seems unlikely that the high current numbers of seabirds could flourish alongside both an industrial fishery and increased stocks of mackerel and gadoids if those stocks were to recover to previous levels observed when there was no sandeel fishery and seabird numbers were lower. Furness and Tasker (2000) showed that the species of seabirds likely to be affected by reductions in sandeel abundance can be predicted with considerable confidence, so that the changes to seabird community composition that would result from reduced sandeel abundance can be anticipated.

\section{Reductions in discharge of discards and offal at sea}

The FAO Code of Conduct for Responsible Fisheries (FAO, 1995), Section 7.2.2 states 'measures should provide that discards and impacts on associated or dependent species are minimized'. This creates a dilemma. Over recent decades, many populations of large scavenging seabirds have increased enormously in size. Several factors may influence these population increases, including the protected status of birds that many decades ago were subject to persecution or harvesting. However, the circumstantial evidence that discards and offal have encouraged population increases is strong (Lloyd et al., 1991; Garthe et al., 1996). Given the current 
trend for reduction in discarding of haddock and whiting, the main discard species in the northern North Sea taken by scavenging seabirds, and predictions of further reductions as a consequence of technical measures and reduced fishing effort currently coming into effect (Reeves and Furness, 2002), we can anticipate conservation problems for scavenging seabirds over coming years.

It would seem logical to look for effects of changes in discarding rates on seabirds by correlating changes in breeding numbers of scavenging seabirds in the northern North Sea with changes in amounts of fish discarded over the last 20 years or so. Unfortunately, such a simple approach is not appropriate. Firstly, the last complete census of breeding seabird numbers was in 1985-87. Trends in breeding seabird numbers since 1987 are not clear as for most species only some sample counts are available and these are not necessarily representative of the population as a whole. Secondly, seabird breeding numbers do not necessarily reflect seabird total population size. Nonbreeders may fill vacancies that arise in the breeding component, such that breeding numbers remain relatively stable even during a period of rapid decrease in total population numbers. An example of such buffering is provided by great skuas in Foula during the 1980s, when numbers of nonbreeders decreased rapidly due to adverse feeding conditions but breeding numbers changed little (Klomp and Furness, 1992). Thirdly, responses of seabird populations will tend to lag behind changes in environmental conditions because seabirds show delayed maturity. Any effect mediated through breeding production will not become evident until several years later, when altered numbers of young birds recruit into the breeding population. If reductions in discarding were to affect breeding numbers, then we must bear in mind that most seabird populations in the North Sea have been increasing. To reverse an increase is like changing the course of a supertanker. It takes time. The cohorts of young birds about to recruit into the population may have to be used up before a decline in breeding numbers can begin. In the case of great skuas, some birds do not start to breed until they are more than 12 years old. The importance of this becomes more obvious when it is appreciated that in a typical scavenging seabird population the breeding adults represent less than $50 \%$ of the fully grown birds; in other words the typical population contains more prebreeding (immature) birds that cannot be censused than breeding birds that are counted. The pool of poten- tial recruits may continue to maintain or even increase breeding numbers for many years after the demographics have shifted to values that in the long term will result in a declining breeding population. It is possible that breeding success of scavenging seabirds might be more clearly and immediately responsive to reductions in discard rates, but the fact that scavenging seabirds feed more on natural foods while breeding and feed more on discards in winter suggests that breeding success may not be very responsive to discard rates and may more often be affected by variations in the abundances of the preferred natural foods. Immature survival through the winter might be the most useful parameter to relate to discard rates, but immature survival rates are difficult to measure and this approach would not be practical at present. Also, this could mean that effects of reduced discarding in the northern North Sea may eventually be seen in terms of breeding numbers in other geographical areas. For example, great black-backed gulls wintering in the northern North Sea include birds that breed in Arctic Norway and Russia.

Reductions in quantities of offal from North Sea fisheries are not predicted to be severe (Reeves and Furness, 2002), and the most pronounced change will be in the amounts of small discards. These small discards are particularly important for great skuas, herring gulls and lesser black-backed gulls Larus fuscus, and it may be these species that will show the most pronounced changes. The highest catches of haddock, whiting, cod and saithe in the North Sea are from areas close to Orkney and Shetland. It is therefore likely that impacts of reduced discarding will be most evident in Orkney and Shetland scavenging seabird populations. Given the likely impact of prey switching by great skuas to killing other seabirds (Furness, 1999b; Oro and Furness, 2002), there is a need to monitor great skua breeding and diet as a consequence of changes in discarding over the coming years. If other feeding opportunities remained unchanged, reductions in discarding might result in reductions in numbers of great skuas, herring gulls and lesser black-backed gulls while having little direct negative effect on populations of northern fulmars, northern gannets or great blackbacked gulls. However, increased predation by great skuas as a consequence of diet switching when discard supplies are low might impact a number of other seabird species on which great skuas may feed, including black-legged kittiwakes, Atlantic puffins Fratercula arctica, European storm petrels 
Hydrobates pelagicus, Leach's petrels Oceanodroma leucorhoa, red-throated divers Gavia stellata, common eiders Somateria mollissima, great blackbacked gulls, and Arctic skuas Stercorarius parasiticus (Phillips et al., 1997, 1998), although variation in sandeel abundance may be a greater influence than variation in discard availability for predation rates of great skuas on other seabirds (Hamer et al., 1991; Ratcliffe et al., 1998a, b, 2002; Catry and Furness, 1999; Ratcliffe and Furness, 1999). Probably bird killing by great skuas will be a function of both sandeel and discard abundance (Caldow and Furness, 2001).

It seems almost inevitable that quantities of fish discarded will reduce further in the North Sea in future. Reducing discarding is a major objective of the FAO's policy for Responsible Fisheries, and is recognised to be a management objective by ICES and the EC as well as national fisheries managements and governments. However, it is not easy to see how best to manage interactions that will arise as a consequence of reductions in discarding. It would be foolish to suggest that rates of discarding should be maintained at current levels 'for the sake of seabirds'. That would not be a practical proposition and even if it could be achieved, it would only serve to perpetuate the imbalance in seabird community composition that now exists in the North Sea as a consequence of many decades of intensive discarding. There may be a case for suggesting that a complete cessation of discarding would be the best strategy to minimise longer term impacts on seabird communities, as this would probably bring seabird populations to a new sustainable equilibrium very much faster than if discarding is slowly reduced over decades. The larger the populations of large scavenging seabirds become as a consequence of continued feeding on discards, the greater the secondary impacts of prey switching by great skuas and the large Larus gulls is likely to be on their prey seabirds. Given that culling would not be an attractive proposition, there is clearly a need for further research into interactions between scavenging seabirds and other wildlife, particularly with regard to consequences of low discarding rates.

\section{ACKNOWLEDGEMENTS}

This work was carried out under sponsorship from the International Fishmeal and Oil Manufacturers Association (IFOMA) and completed during funding from the EC (DISCBIRD). This review has benefited greatly from collaborations among the members of the ICES Working Group on Seabird Ecology, where seabird-fishery interactions have been a major term of reference, and I particularly thank Tycho Anker-Nilssen, Rob Barrett, Peter Becker, Kees Camphuysen, Gilles Chapdelaine, Petter Fossum, Stefan Garthe, Simon Greenstreet, George Hunt, Ommo Hüppop, Mardik Leopold, Bill Montevecchi, Jim Reid, Mark Tasker, Uve Walter and Peter Wright for their stimulating contributions to these ICES Working Group meetings of recent years, and the ICES secretariat for hosting and supporting our Working Group.

\section{REFERENCES}

Abrams, R.W. - 1983. Pelagic seabirds and trawl-fisheries in the southern Benguela Current region. Mar. Ecol. Prog. Ser., 11: 151-156.

Aebischer, N.J., J.C. Coulson and J.M. Colebrook. - 1990. Parallel long-term trends across four marine trophic levels and weather. Nature, 347: 753-755.

Ainley, D.G., W.J. Sydeman and J. Norton. - 1995. Upper trophic level predators indicate interannual negative and positive anomalies in the California Current food web. Mar. Ecol. Prog. Ser., 118: 69-79.

Alverson, D.L., M.H. Freeberg, S.A. Murawski and J.G. Pope. 1994. A global assessment of fisheries bycatch and discards. FAO Fisheries Technical Paper 339.

Anker-Nilssen, T., R.T. Barrett and J.V. Krasnov. - 1997. Longand short-term responses of seabirds in the Norwegian and Barents Sea to changes in stocks of prey fish. In: Proceedings Forage Fishes in Marine Ecosystems, pp. 683-698. Alaska Sea Grant College Program, Fairbanks.

Arcos, J.M. and D. Oro. - 1996. Changes in foraging range of Audouin's gulls Larus audouinii in relation to a trawler moratorium in the western Mediterranean. Colonial Waterbirds, 19: $128-131$.

Arcos, J.M., X. Ruiz, S. Bearhop and R.W. Furness. - 2002. Mercury levels in seabirds and their fish prey at the Ebro Delta (NW Mediterranean): the role of trawler discards as a source of contamination. Mar. Ecol. Prog. Ser., in press.

Bailey, R.S., R.W. Furness, J.A. Gauld and P.A. Kunzlik. - 1991. Recent changes in the population of the sandeel (Ammodytes marinus Raitt) at Shetland in relation to estimates of seabird predation. ICES Mar. Sci. Symp., 193: 209-216.

Barrett, R.T. and R.W. Furness. - 1990. The prey and diving depth of seabirds on Hornøy, north Norway after a decrease in Barents Sea capelin stock. Ornis Scand., 21: 179-186.

Barrett, R.T. and J.V. Krasnov. - 1996. Recent responses to changes in fish stocks of prey species by seabirds breeding in the southern Barents Sea. ICES J. Mar. Sci., 53: 713-722.

Belda, E.J. and A. Sánchez. - 2001. Seabird mortality on longline fisheries in the western Mediterranean: factors affecting bycatch and proposed mitigating measures. Biol. Conserv., 98: 357-363.

Berghahn, R. and H.U. Rösner. - 1992. A method to quantify feeding of seabirds on discard from the shrimp fishery in the North Sea. Neth. J. Sea Res., 28: 347-350.

Blaber, S.J.M. and T.J. Wassenberg. - 1989. Feeding ecology of the piscivorous birds Phalacrocorax varius, P. melanoleucos and Sterna bergii in Moreton Bay, Australia: diets and dependence on trawler discards. Mar. Biol., 101: 1-10.

Blaber, S.J.M., D.A. Milton, G.C. Smith and M.J. Farmer. - 1995. Trawl discards in the diets of tropical seabirds of the northern Great Barrier Reef, Australia. Mar. Ecol. Prog. Ser., 127: 1-13. Bogstad, B. and S. Mehl. - 1997. Interactions between Atlantic cod 
(Gadus morhua) and its prey species in the Barents Sea. In: Proceedings Forage Fishes in Marine Ecosystems, pp. 591615. Alaska Sea Grant College Program, Fairbanks.

Brothers, N.P., J. Cooper and S. Løkkeborg. - 1999. The incidental catch of seabirds by longline fisheries: worldwide review and technical guidelines for mitigation. FAO Fisheries Circular No. 937. FAO, Rome.

Cairns, D.K. - 1987. Seabirds as indicators of marine food supplies. Biol. Oceanogr., 5:261-271.

Caldow, R.W.G. and R.W. Furness. - 2001. Does Holling's disc equation explain the functional response of a kleptoparasite? $J$. Anim. Ecol., 70: 650-662.

Camphuysen, C.J. - 1994. Flatfish selection by herring gulls Larus argentatus and lesser black-backed gulls Larus fuscus scavenging at commercial beamtrawlers in the southern North Sea. Neth. J. Sea Res., 32: 91-98.

Camphuysen, C.J., B. Calvo, J. Durinck, K. Ensor, A. Follestad, R.W. Furness, S. Garthe, G. Leaper, H. Skov, M.L. Tasker and C.J.N. Winter. - 1995. Consumption of discards by seabirds in the North Sea. NIOZ Rapport 1995-5. Netherlands Institute for Sea Research, Texel.

Catry, P.and R.W. Furness. - 1999. The influence of adult age on territorial attendance by breeding great skuas Catharacta skua: an experimental study. J. Avian Biol., 30: 399-406.

Chapdelaine, G. and J.F. Rail. - 1997. Relationship between cod fishery activities and the population of herring gulls on the north shore of the Gulf of St. Lawrence, Québec, Canada. ICES J. Mar. Sci., 54: 708-713.

Croxall, J.P. and R. Gales. - 1997. An assessment of the conservation status of albatrosses. In: G. Robertson and R. Gales (eds.), Albatross Biology and Conservation, pp. 46-65. Surrey Beatty and Sons, Chipping Norton.

Dändliker, G. and G. Mülhauser. - 1988. L'exploitation des déchets de chalutage par les oiseaux de mer au large des Orcades et des Shetland (Nord-Est Atlantique). Nos Oiseaux, 39: 257-288.

DeGange, A.R., R.H. Day, J.E. Takekawa and V.M. Mendenhall. 1993. Losses of seabirds in gill nets in the North Pacific. In: The Status, Ecology and Conservation of Marine Birds of the North Pacific. Canadian Wildlife Service Special Publication, Ottawa.

Duffy, D.C. - 1983. Environmental uncertainty and commercial fishing: effects on Peruvian guano birds. Biol. Conserv., 26 227-238.

Dunn, E. - 1994. Interactions between fisheries and marine birds: Research Recommendations. RSPB, Sandy.

Dunn, E. - 1995. Global Impacts of Fisheries on Seabirds. BirdLife International, Cambridge

Evans, S.M., J.E. Hunter and R.I. Wahju. - 1994. Composition and fate of the catch and bycatch in the Farne Deep (North Sea) Nephrops fishery. ICES J. Mar. Sci., 51: 155-168

FAO. - 1995. Code of conduct for responsible fisheries. FAO, Rome.

Freeman, A.N.D. - 1997. The influence of hoki fishing vessels on Westland petrel (Procellaria westlandica) distribution at sea. Notornis, 44: 159-164.

Freeman, A.N.D. and P.J. Smith. - 1998. Iso-electric focusing and the identification of fisheries' waste in the diet of Westland petrels (Procellaria westlandica). N.Z. J. Mar. Freshwater Res., 32: 177-180.

Furness, R.W. - 1990. A preliminary assessment of the quantities of Shetland sandeels taken by seabirds, seals, predatory fish and the industrial fishery in 1981-1983. Ibis, 132: 205-217.

Furness, R.W. - 1999a. Does harvesting a million metric tons of sand lance per year from the North Sea threaten seabird populations? In: Ecosystem Approaches for Fisheries Management, pp. 407-424. Alaska Sea Grant College Program AK-SG-99-01, Fairbanks.

Furness, R.W. - 1999b. Will reduced discarding help or harm seabird populations? In: Ecosystem Approaches for Fisheries Management, pp. 481-488. Alaska Sea Grant College Program AK-SG-99-01, Fairbanks.

Furness, R.W. - 2002. Management implications of interactions between fisheries and sandeel-dependent seabirds and seals in the North Sea. ICES J. Mar. Sci.,

Furness, R.W., K. Ensor and A.V. Hudson. - 1992. The use of fishery waste by gull populations around the British Isles. Ardea, 80: $105-113$

Furness, R.W. and C.J. Camphuysen. - 1997. Seabirds as monitors of the marine environment. ICES J. Mar. Sci., 54: 726-737.

Furness, R.W. and M.L. Tasker. - 1997. Seabird consumption in sand lance MSVPA models for the North Sea, and the impact of industrial fishing on seabird population dynamics. In: Proceedings Forage Fishes in Marine Ecosystems, pp. 147-169. Alaska Sea Grant College Program, Fairbanks.

Furness, R.W. and M.L. Tasker. - 2000. Seabird-fishery interactions: quantifying the sensitivity of seabirds to reductions in sandeel abundance and identification of key areas for sensitive seabirds in the North Sea. Mar. Ecol. Prog. Ser., 202: 253-264.

Garthe, S. and O. Hüppop. - 1994. Distribution of ship-following seabirds and their utilization of discards in the North Sea in summer. Mar. Ecol. Prog. Ser., 106: 1-9.

Garthe, S., C.J. Camphuysen and R.W. Furness. - 1996. Amounts of discards by commercial fisheries and their significance as food for seabirds in the North Sea. Mar. Ecol. Prog. Ser., 136: $1-11$.

Garthe, S., U. Walter, M.L. Tasker, P.H. Becker, G. Chapdelaine and R.W. Furness. - 1999. Evaluation of the role of discards in supporting bird populations and their effects on the species composition of seabirds in the North Sea. In: Diets of Seabirds and Consequences of Changes in Food Supply, pp. 29-41. ICES Cooperative Research Report No. 232. ICES, Copenhagen.

Gislason, H. and E. Kirkegaard. - 1996. The industrial fishery and the North Sea Sandeel stock. Seminar on the Precautionary Approach to North Sea Fisheries Management, Oslo, 9-10 September 1996.

Gjøsæter, H. - 1995. Pelagic fish and the ecological impact of the modern fishing industry in the Barents Sea. Arctic, 48: 267-278.

Gjøsæter, H. - 1997. The Barents Sea capelin stock (Mallotus villosus): A brief review. In: Proceedings Forage Fishes in Marine Ecosystems, pp. 469-484. Alaska Sea Grant College Program, Fairbanks.

Hamer, K.C., R.W. Furness and R.W.G. Caldow. - 1991. The effects of changes in food availability on the breeding ecology of great skuas Catharacta skua in Shetland. J. Zool., Lond., 223: $175-188$

Hamer, K.C., P. Monaghan, J.D. Uttley, P. Walton and M.D. Burns. - 1993. The influence of food supply on the breeding ecology of kittiwakes Rissa tridactyla in Shetland. Ibis, 135: 255-263.

Harris, M.P. and S. Wanless. - 1990. Breeding success of kittiwakes Rissa tridactyla in 1986-88: Evidence for changing conditions in the northern North Sea. J. Appl. Ecol., 27: 172-187.

Harris, M.P. and S. Wanless. - 1997. Breeding success, diet, and brood neglect in the kittiwake (Rissa tridactyla) over an 11year period. ICES J. Mar. Sci., 54: 615-623.

Harris, M.P. and R.S. Bailey. - 1992. Mortality rates of puffin Fratercula arctica and guillemot Uria aalge and fish abundance in the North Sea. Biol. Conserv. 60: 39-46.

Heubeck, M. - 1989. Seabirds and Sandeels: proceedings of a seminar held in Lerwick, Shetland, 15-16 October 1988. Shetland Bird Club, Lerwick.

Heubeck, M., P.V. Harvey and J.D. Okill. - 1991. Changes in the Shetland guillemot Uria aalge population and the pattern of recoveries of ringed birds, 1959-1990. Seabird, 13: 3-21.

Heubeck, M., R.M. Mellor and P.V. Harvey. - 1997. Changes in the breeding distribution and numbers of kittiwakes Rissa tridacty$l a$ around Unst, Shetland, and the presumed role of predation by great skuas Stercorarius skua. Seabird, 19: 12-21.

Heubeck, M., R.M. Mellor, P.V. Harvey, A.R. Mainwood, and R. Riddington. - 1999. Estimating the population size and rate of decline of kittiwakes Rissa tridactyla breeding in Shetland, 1981-97. Bird Study, 46: 48-61.

Howes, L.A. and W.A. Montevecchi. - 1992. Population trends of gulls and terns in Gros Morne National Park, Newfoundland. Can. J. Zool., 71: 1516-1520.

Hudson, A.V. - 1989. Interspecific and age-related differences in the handling time of discarded fish by scavenging seabirds. Seabird, 12: 40-44.

Hudson, A.V. and R.W. Furness. - 1988. Utilization of discarded fish by scavenging seabirds behind whitefish trawlers in Shetland. J. Zool., Lond., 215: 151-166.

Hudson, A.V. and R.W. Furness. - 1989. The behaviour of seabirds foraging at fishing boats around Shetland. Ibis, 131: 225-237.

Hunt, G.L., W.A. Montevecchi and M.F. Leopold. - 1999. A review of issues related to seabird consumption of fish and shellfish stocks, discards and mariculture as well as the trophic role and ecology of seabirds and waders. In: Diets of Seabirds and Con- 
sequences of Changes in Food Supply, pp. 2-5. ICES Cooperative Research Report No. 232. ICES, Copenhagen.

Hüppop, O. and S. Wurm. - 2000. Effects of winter fishery activities on resting numbers, food and body condition of large gulls Larus argentatus and L. marinus in the south-eastern North Sea. Mar. Ecol. Prog. Ser. 194: 241-247.

ICES. - 1997. Report of the multispecies assessment working group, ICES headquarters 11-19 August 1997. ICES CM1997/Assess: 16, $235 \mathrm{pp}$.

ICES. - 1998. Report of the Working Group on Ecosystem Effects of Fishing Activities. ICES CM 1998/ACFM/ACME:1 Ref.:E

King, W.B. -1984. Incidental mortality of seabirds in gillnets in the North Pacific. In: J.P. Croxall, P.G.H. Evans and R.W. Schreiber (eds.), Status and Conservation of the World's Seabirds, pp. 709-715. ICBP Tech. Publication No. 2. ICBP, Cambridge.

Klomp, N.I. and R.W. Furness. - 1992. Non-breeders as a buffer against environmental stress: declines in numbers of great skuas on Foula, Shetland, and prediction of future recruitment. J. Appl. Ecol., 29: 341-348.

Krasnov, J.V. and R.T. Barrett. - 1995. Large-scale interactions among seabirds, their prey and humans in the southern Barents Sea. In: H.R Skjoldal, C. Hopkins, K.E. Erikstad and H.P. Leinaas (eds.), Ecology of fjords and coastal waters, pp. 443456. Elsevier Science B.V., Amsterdam.

Lloyd, C., M.L. Tasker and K. Partridge. - 1991. The status of seabirds in Britain and Ireland. Poyser, London.

Mehlum, F. and G.W. Gabrielsen. - 1995. Energy expenditure and food consumption by seabird populations in the Barents Sea region. In: H.R Skjoldal, C. Hopkins, K.E. Erikstad and H.P. Leinaas (eds.), Ecology of fjords and coastal waters, pp. 457470. Elsevier Science B.V, Amsterdam.

Melvin, E.F. and J.K. Parrish. - 2001. Seabird bycatch: trends, roadblocks, and solutions. University of Alaska Sea Grant, Fairbanks.

Montevecchi, W.A. - 1991. Incidence and types of plastic in gannets' nests in the northwest Atlantic. Can. J. Zool., 69: 295-297.

Montevecchi, W.A. - 1993. Birds as indicators of change in marine prey stocks. In: R.W. Furness and J.J.D. Greenwood (eds.), Birds as Monitors of Environmental Change, pp. 217-265. Chapman and Hall, London.

Moore, G. and S. Jennings. - 2000. Commercial fishing: The wider ecological impacts. Blackwell Scientific, London.

Murray, T.E., J.A. Bartle, S.R. Kalish and P.R. Taylor. - 1993. Incidental capture of seabirds by Japanese southern bluefin tuna longline vessels in New Zealand waters, 1988-1992. Bird Conserv. Int., 3: 181-210.

Noordhuis, R. and A.L. Spaans. - 1992. Interspecific competition for food between herring Larus argentatus and lesser blackbacked gulls $L$. fuscus in the Dutch Wadden Sea area. Ardea, 80: 115-132.

Ojowski, U., C. Eidtmann, R.W. Furness and S. Garthe. - 2001. Diet and nest attendance of incubating and chick-rearing northern fulmars (Fulmarus glacialis) in Shetland. Mar. Biol., 139: 1193-1200.

Oro, D. - 1996. The effects of trawler discard availability on the egg-laying and the breeding success of the lesser black-backed gull Larus fuscus in western Mediterranean. Mar. Ecol. Prog. Ser., 132: 43-46.

Oro, D. and A. Martínez-Vilalta. - 1994. Factors affecting kleptoparasitism and predation rates upon a colony of Audouin's gull (Larus audouinii) by yellow-legged gulls (Larus cachinnans) in Spain. Colonial Waterbirds, 17: 35-41.

Oro, D. and X. Ruiz. - 1997. Exploitation of trawler discards by breeding seabirds in the north-western Mediterranean: Differences between the Ebro Delta and the Balearic Islands areas. ICES J. mar Sci., 54: 695-707.

Oro, D. and R. Pradel. - 1999. Recruitment of Audouin's gull to the Ebro Delta colony at metapopulation level in the western Mediterranean. Mar. Ecol. Prog. Ser., 180: 267-273.

Oro, D. and R. Pradel. - 2000. Determinants of local recruitment in a growing colony of Audouin's gull. J. Anim. Ecol., 69: 1-14.

Oro, D. and R.W. Furness. - 2002. Influences of food availability and predation on survival of kittiwakes. Ecology.

Oro, D., M. Bosch and X. Ruiz. - 1995. Effects of a trawling moratorium on the breeding success of the yellow-legged gull Larus cachinnans. Ibis, 137: 347-349.

Oro, D., L. Jover and X. Ruiz. - 1996a. Influence of trawling activ- ity on the breeding ecology of a threatened seabird, Audouin's gull Larus audouinii. Mar. Ecol. Prog. Ser., 139: 19-29.

Oro, D., X. Genovart, X. Ruiz, J. Jiménez, and J. García-Gans. 1996b. Differences in diet, population increase and breeding performance between two colonies of Audouin's Gulls Larus audouinii during breeding seasons affected by a trawling moratorium. J. Avian Biol., 27: 245-251.

Oro, D., X. Ruiz, L. Jover, V. Pedrocchi and J. Gonzalez-Solis. 1997. Diet and adult time budgets of Audouin's gull Larus audouinii in response to changes in commercial fisheries. Ibis, 139: 631-637.

Oro, D., R. Pradel, and J.-D. Lebreton. - 1999. The effects of nest predation and food availability on life history traits in Audouin's gull. Oecologia, 118: 438-445.

Paterson, A.M., A. Martínez-Vilalta and J.I. Dies. - 1992. Partial breeding failure of Audouin's gull in two Spanish colonies in 1991. Brit. Birds, 85: 97-100.

Phillips, R.A., R.W.G. Caldow and R.W. Furness. - 1996. The influence of food availability on the breeding effort and reproductive success of Arctic skuas Stercorarius parasiticus. Ibis, 138: 410-419.

Phillips, R.A., P. Catry, D.R. Thompson, K.C. Hamer and R.W. Furness. - 1997. Inter-colony variation in diet and reproductive performance of great skuas Catharacta skua. Mar. Ecol. Prog. Ser., 152: 285-293.

Phillips, R.A., R.W. Furness and F.M. Stewart. - 1998. The influence of territory density on the vulnerability of Arctic skuas Stercorarius parasiticus to predation. Biol. Conserv., 86: 21-31.

Phillips, R.A., D.R. Thompson, and K.C. Hamer. - 1999. The impact of great skua predation on seabird populations at St Kilda: a bioenergetics model. J. Appl. Ecol., 36: 218-232.

Piatt, J.F., D.N. Nettleship, and W. Threlfall. - 1984. Net mortality of common murres and puffins in Newfoundland, 19511981. In: D.N Nettleship, G.A. Sanger and P.F. Springer (eds.), Marine Birds: Their Feeding Ecology and Commercial Fisheries Relationships, pp. 196-207 Canadian Wildlife Service, Ottawa.

Ratcliffe, N. and R.W. Furness. - 1999. The effect of parental age and experimentally-manipulated brood size on the foraging effort and breeding performance of great skuas Catharacta skua. J. Zool., Lond., 249: 195-201.

Ratcliffe, N., R.W. Furness, and K.C. Hamer. - 1998a. The interactive effects of age and food supply on the breeding ecology of great skuas. J. Anim. Ecol., 67: 853-862.

Ratcliffe, N., R.W. Furness and N.I. Klomp. - 1998b. Influences of breeding experience on the reproductive performance of great skuas Catharacta skua. J. Avian Biol., 29: 293-298.

Ratcliffe, N., P. Catry, K.C. Hamer, N.I. Klomp and R.W. Furness. - 2002. The effect of age and year on the survival of breeding adult great skuas Catharacta skua in Shetland. Ibis, 144:

Reeves, S.A. and R.W. Furness. - 2002. Net loss - seabirds gain? Implications of fisheries management for seabirds scavenging discards in the northern North Sea. RSPB, Sandy.

Regehr, H.M. and W.A. Montevecchi. - 1996. Interactive effects of food shortage and predation on breeding failure of black-legged kittiwakes: effects of fisheries activities and implications for indicator species. Mar. Ecol. Prog. Ser., 155: 249-260.

Rindorf, A., S. Wanless and M.P. Harris. - 2000. Effects of changes in sandeel availability on the reproductive output of seabirds. Mar. Ecol. Prog. Ser., 202: 241-252.

Russell, J.O. and W.A. Montevecchi. - 1996. Predation on adult puffins Fratercula arctica by great black-backed gulls Larus marinus at a Newfoundland colony. Ibis, 138: 791-794.

Ryan, P.G. and C.L. Moloney. - 1988. Effect of trawling on bird and seal distributions in the southern Benguela region. Mar. Ecol. Prog. Ser., 45: 1-11.

Springer, A.M. and S.G. Speckman. - 1997. A forage fish is what? Summary of the Symposium. Proceedings Forage Fishes in Marine Ecosystems, pp. 773-794. Alaska Sea Grant College Program, Fairbanks.

Stratoudakis, Y., R.J. Fryer and R.M. Cook. - 1998. Discarding practices for commercial gadoids in the North Sea. Can. J. Fish. Aquat. Sci., 55: 1632-1644.

Stratoudakis, Y., R.J. Fryer, R.M. Cook and G.J. Pierce. - 1999. Fish discarded from Scottish demersal vessels: Estimators of total discards and annual estimates for targeted gadoids. ICES J. Mar. Sci., 56: 592-605.

Tasker, M.L., P.H. Becker and G. Chapdelaine. - 1999. Exploration 
of the short- and medium-term consequences of a reduction in the amounts of fish discarded. In: Diets of Seabirds and Consequences of Changes in Food Supply, 42-46. ICES Cooperative Research Report No. 232. ICES, Copenhagen.

Tasker, M.L., C.J. Camphuysen, J. Cooper, S. Garthe, W.A. Montevecchi and S.J.M. Blaber. - 2000. The impacts of fishing on marine birds. ICES J. Mar. Sci., 57: 531-547.

Thompson, K.R. - 1992. Quantitative analysis of the use of discards from squid trawlers by black-browed albatrosses in the vicinity of the Falkland Islands. Ibis, 134: 11-21.

Thompson, K.R. and M.D. Riddy. - 1995. Utilization of offal and discards from 'fin-fish' trawlers around the Falkland Islands by the black-browed albatross Diomedea melanophris. Ibis, 137 198-206.

Thompson, K.R., E. Brindley and M. Heubeck. - 1997. Seabird numbers and breeding success in Britain and Ireland, 1996. Joint Nature Conservation Committee, Peterborough.

Vader, W., R.T. Barrett, K.E. Erikstad and K.B. Strann. - 1990. Differential responses of common and thick-billed murres to a crash in the capelin stock in the southern Barents Sea. Studies in Avian Biology 14, 175-180.

Votier, S.C., S. Bearhop, N. Ratcliffe and R.W. Furness 2001. Pellets as indicators of diet in great skuas Catharacta skua. Bird Study 48, 373-376.

Walter, U. - 1997. Quantitative analysis of discards from brown shrimp trawlers in the coastal area of the East Frisian islands. Arch. Fish. Mar. Res. 45, 61-76.

Walter, U. and P.H. Becker. - 1994. The significance of discards from the brown shrimp fisheries for seabirds in the Wadden Sea - preliminary results. Ophelia, Suppl. 6, 253-262.

Walter, U. and P.H Becker. - 1998. Influence of physical factors and fishing activity on the occurrence of seabirds scavenging around shrimpers in the Wadden Sea. Senckenbergiana maritima 29, 155-162.

Weimerskirch, H., A. Catard, P.A. Prince, Y. Cherel and J.P. Croxall. - 1999. Foraging white-chinned petrels Procellaria aequinoctialis at risk from the tropics to Antarctica. Biol. Conserv. 87, 273-275.

Weimerskirch, H., D. Capdeville and G. Duhamel. - 2000. Factors affecting the number and mortality of seabirds attending trawlers and long-liners in the Kerguelen area. Polar Biology 23, 236-249.

Wright, P.J. - 1996. Is there a conflict between sandeel fisheries and seabirds? A case study at Shetland. In: S.P.R Greenstreet and M.L. Tasker (eds.), Aquatic predators and their prey, pp. 154165. Fishing News Books, Oxford.

Wright, P., R.T. Barrett., S.P.R. Greenstreet, B. Olsen and M. Tasker. - 1997. Effect of fisheries for small fish on seabirds in the eastern Atlantic. In: G.L. Jr Hunt and R.W. Furness (eds.), Seabird/fish interactions, with particular reference to seabirds in the North Sea, pp. 44-55. ICES Cooperative Research Report No. 216, Copenhagen.

Wright, P.J. and G.S. Begg. - 1997. A spatial comparison of common guillemots and sandeels in Scottish waters. ICES J. Mar. Sci. 54: 578-592. 
